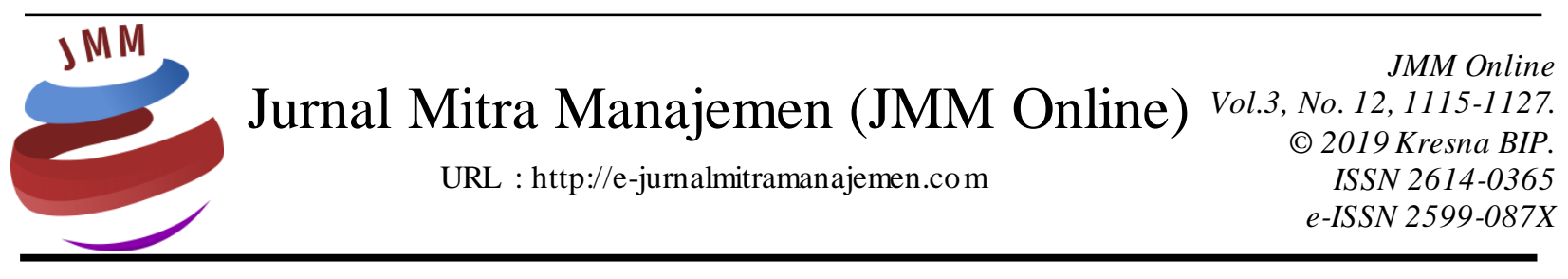

\title{
REGULASI DAN SANKSI TERHADAP TENDENSI PLAGIARISME \\ (Studi pada Mahasiswa Akuntansi di Lingkungan \\ Politeknik Negeri Bengkalis)
}

\author{
Nur Anita 1), Husni Mubarak 2) \\ Politeknik Negeri Bengkalis
}

INFORMASI ARTIKEL

Dikirim : 03 Desember 2019

Revisi pertama : 10 Desember 2019

Diterima : 13 Desember 2019

Tersedia online : 31 Desember 2019

Kata Kunci : Plagiarisme, Mahasiswa Akuntansi, Structural Equation Modeling, Regulasi, Sanksi.

Email : nuranita@polbeng.ac.id ${ }^{1)}$, husnimubarak@pobleng.ac.id ${ }^{2)}$

\section{ABSTRAK}

Artikel ini menyajikan berbagai macam faktor yang dapat mengurangi perilaku mahasiswa dalam melakukan plagiat sehingga apabila faktor-faktor tersebut diabaikan maka tendensi untuk melakukan plagiarisme semakin meningkat. Isu plagiat menjadi isu yang menarik minat dan perhatian berbagai organisasi pendidik terutama calon akuntan. Dengan menggunakan Structural Equation Modeling, penelitian ini menggunakan metode survei dengan 44 partisipan yang berasal dari mahasiswa Akuntansi Politeknik Negeri Bengkalis. Hasil menunjukkan temuan yang signifikan bahwa ketiadaan regulasi yang dimediasi dengan sanksi akan meningkatkan kecenderungan mahasiswa dalammelakukan tindakan plagiarisme. Penelitian ini membantu perkembangan penelitian dalam ranah melayu dengan memberikan gambaran mengenai perilaku plagiarisme mahasiswa khususnya di lingkungan Politeknik Negeri Bengkalis. 


\section{PENDAHULUAN \\ Latar Belakang}

Isu mengenai plagiarisme telah menjadi isu menarik belakangan ini. Isu plagiarisme telah menjadi minat dan intens yang kuat bagi semua instansi pendidikan saat ini. Hal ini disebabkan karena maraknya praktek plagiarisme di kalangan mahasiswa seiring dengan adanya kemudahan dalam mengakses berbagai macam informasi di internet. Para pendidik pada pendidikan tinggi telah banyak menghadapi kasus plagiarisme di kelas (Jereb dkk, 2018). Sehingga, minat mengenai isu plagiarisme semakin menguat karena adanya permintaan untuk meningkatkan kualitas akuntan yang profesional dan memiliki nilai etis yang baik (ICAS, 2007a; 2007B; IFAC, 2007).

Skandal besar seperti Enron, WorldCom dan Palvamart menjadi peringatan bagi akuntan untuk memiliki sikap profesionalisme dan menjauh dari tindakan kecurangan. Kebanyakan paper akuntansi saat ini tidak pernah absen dalam menyebut beberapa skandal besar terkait nama-nama perusahaan di atas. Hal ini disebabkan karena tindakan ini telah mencoreng nama baik akuntan sehingga menyebabkan hilangnya kepercayaan kepada para akuntan di masa depan. Oleh karena itu, profesi akuntansi, baik secara domestik maupun profesional saat ini lebih ketat dalam praktek etis dengan para membernya (Koh dkk, 2011). Sarbanes Oxley Act 2002 di Amerika Serikat, Laporan Smith (2003) di Inggris, dan the Corporate Law Economic Reform Program (Audit Reform and Corporate Discosure) Act 2004 di Australia menjadi respon profesi akuntan terhadap skandal ini. Di samping itu, sebagai organisasi yang akan melahirkan banyak akuntan profesional, organisasi pendidik memiliki kewajiban untuk memastikan akuntan yang mereka hasilkan merupakan akuntan pendidik yang memiliki sikap profesional dan etika yang baik.

Kebanyakan perilaku plagiarisme mengetahui dan mengerti jika yang mereka lakukan adalah perbuatan yang salah dan tidak bermoral, namun mereka beranggapan bahwa pendidik tidak akan menemukan kecurangan yang mereka lakukan (Dhusia, 2017). Penelitian yang dilakukan oleh Center for Adademic Integrity menemukan bahwa $80 \%$ mahasiswa mengakui melakukan beberapa kecurangan akademis dan survei yang dilakukan oleh Psychological Record menunjukkan bahwa 36\% mahasiswa menggunakan internet untuk melakukan tindakan plagiat (https://www.checkforplagiarism.net/cyber-plagiarism). Bukti bahwa maraknya perilaku tidak jujur dikalangan mahasiswa akuntansi merupakan sesuatu yang sangat mengganggu mengingat mereka nantinya akan terlibat dalam profesi akuntansi (Smith dkk, 2007). Untuk mewujudkan nilai-nilai ini organisasi pendidik bukan hanya harus memahami faktor yang mendorong mahasiswa akuntansi sebagai calon akuntan dalam melakukan kecurangan, namun juga penting bagi organisasi pendidik untuk meningkatkan berbagai faktor yang mampu mengurangi kecenderungan perilaku plagiarisme oleh mahasiswa. Hal penting lain yang harus digarisbawahi adalah bahwa mahasiswa akuntansi kelak akan menjadi akuntan profesional dan akan menjadi pemimpin bisnis dimasa depan (Guo, 2011). Mereka akan dihadapkan dengan banyak masalah seiring dengan perkembangan teknologi dan era globalisasi yang semakin meningkat, jika mahasiswa tidak memiliki perilaku etis yang baik maka tindakan 
plagiarisme ini akan berkembang ke tindakan seperti fraud, slack dan berbagai tindakan kecurangan lainnya.

Banyak penelitian yang sudah dilakukan terkait dengan faktor-faktor yang menyebabkan terjadinya plagiarisme di universitas (Smith dkk, 2007; Koh dkk, 2011; Ahmadi., 2014; Dhusia, 2017; Jereb dkk., 2018). Penelitian sebelumnya mengidentifikasi beberapa faktor yang berkontribusi dalam terjadinya plagiarisme. Namun, masih sedikit yang meneliti faktor-faktor apa yang dapat mengurangi tindakan plagiarisme. Hal ini menimbulkan pertanyaan, dapatkah perilaku plagiarisme ini dicegah? Faktor-faktor apa saja yang berkontribusi dalam mencegah terjadinya plagiarisme?.

Penelitian ini menawarkan beberapa variabel sebagai faktor-faktor yang dapat mengurangi kecenderungan seseorang melakukan plagiarisme sehingga apabila faktorfaktor atau variabel ini diabaikan, kecenderungan untuk melakukan tindakan plagiarisme akan semakin kuat. Variabel yang dimaksud adalah regulasi dan sanksi. Gagasan munculnya regulasi dan sanksi sebagai faktor yang dapat mempengaruhi terjadinya plagiat di kalangan mahasiswa adalah disebabkan karena proses pembelajaran mahasiswa di kelas tidak dapat dipisahkan dengan aturan-aturan yang berlaku di institusi serta selalu ada sanksi bagi yang melanggar regulasi di institusi. Oleh karena itu, penting untuk mempertimbangkan regulasi dan sanksi sebagai faktor yang dapat mengurangi kecenderungan mahasiswa dalam melakukan tindakan plagiarisme. Penelitian ini berusaha menjawab pertanyaan penelitian di atas dengan menyajikan berbagai variabel yang dianggap dapat mengurangi perilaku mahasiswa dalam melakukan tindakan plagiarisme dan kecurangan. Dengan menggunakan metode survei dengan partisipan dari 44 (empat puluh empat) mahasiswa Akuntansi di Lingkungan Politeknik Negeri Bengkalis. Hasil penelitian menunjukkan bahwa tidak adanya regulasi dan tanpa adanya sanksi dari regulasi dapat meningkatkan kecenderungan mahasiwa dalam melakukan plagiarisme. Oleh karena itu, penting bagi universitas dan instansi pendidikan untuk mulai menerapkan regulasi mengenai plagiarisme dan sanksi kepada mahasiswa yang terdeteksi melakukan tindakan plagiarisme.

Penelitian ini juga menggunakan teori kepatuhan sebagai teori yang mampu memperkuat regulasi dan sanksi sebagai faktor-faktor yang mampu mengurangi tendensi tindakan plagiarisme. Penelitian ini berkontribusi dalam perkembangan literatur dengan menyajikan dengan terperinci faktor yang dapat mengurangi tendensi mahasiswa dalam melakukan tindakan plagiarisme. Penelitian ini juga memberikan bukti empiris bahwa tidak adanya regulasi secara signifikan dapat meningkatkan kecenderungan mahasiswa melakukan tindakan plagiarisme melalui mediasi sanksi, hasil penelitian menunjukkan hasil yang serupa untuk variabel sanksi dengan pengujian secara langsung. Bagi organisasi pendidik, penelitian ini dapat memberikan gambaran mengenai perilaku mahasiswa dalam kecenderungannya untuk melakukan plagiarisme. Sehingga, penelitian ini dapat membantu peningkatan kualitas mahasiswa sebagai calon akuntan yang memiliki sikap dan etika yang baik dengan cara mereduce perilaku plagiarisme. Kecurangan berakar dari sesuatu hal yang terlihat kecil dan sederhana kemudian akan merambah ke sesuatu yang lebih besar. Jika bisa mencegah dari akarnya untuk tumbuh, kenapa tidak?. 


\section{Rumusan Masalah}

Adapun rumusan masalah dari penelitian ini, adalah dapatkah sanksi memediasi hubungan regulasi dalam mengurangi kemungkinan terjadinya plagiarisme?

\section{Tujuan Penelitian}

Berdasarkan rumusan masalah diatas, maka tujuan dalam penelitian ini adalah untuk mengetahui apakah sanksi dapat memediasi hubungan regulasi dalam mengurangi kemungkinan terjadinya plagiarism.

\section{KAJIAN PUSTAKA \\ Plagiarisme}

Plagiarisme dalam kamus Oxford Learner's Pocket Dictionary (2008) diartikan sebagai "copy another person's work, words, ideas, etc and pretend that they are your own". Maurer dkk., (2006) mendefinisikan tindakan plagiarisme sebagai:

“a) turning in someone else's work as your own; b) copying words or ideas from someone else without giving credit; c) failing to put a quotation in quotation marks; d) giving incorrect information about the source of a quotation; e) changing words but copying the sentence structure of a source without giving credit; f) copying so many words or ideas from a source that it makes up the majority of your work, whether you give credit or not"

Dari definisi di atas maka plagiarisme dapat dikatakan sebagai tindakan mencatut ide atau karya orang lain tanpa mencantumkan sumber yang jelas dan mengakuinya sebagai milik sendiri atau sebagai karya pribadi atau tindakan mengubah kata tetapi menyalin secara terstruktur sebuah sumber tanpa memberikan kredit yang jelas mengenai sumber tulisan. Tindakan mencatut ide orang lain tidak hanya bisa dilakukan ketika menulis penelitian, tetapi juga ketika mengerjakan makalah yang diberikan oleh dosen. Saat ini, akses informasi dipermudah dengan adanya perkembangan teknologi (Jereb dkk, 2018) yang kemudian dapat menyebabkan mudahnya mahasiswa dalam menyalin tulisan karena adanya kebebasan dalam mengakses dan kurangnya edukasi terkait plagiarisme. Kemudahan dalam mengakses internet dapat menjadi salah satu pemicu munculnya sikap plagiarisme. Selain itu, tindakan plagiarisme dapat saja terjadi karena tidak disengaja misal plagiarisme timbul karena kurangnya pemahaman mengenai apa itu plagiarisme, kurangnya pemahaman tentang bagaimana memilih referensi akademik yangsesuai atau kurangnya keterampilan menulis akademik (James dan Devlin, 2002; Devlin dan Gray, 2007). Plagiarisme termasuk salah satu tindakan tidak terpuji dan dapat merugikan orang lain.

Penelitian sebelumnya telah mencoba mengidentifikasi sebab-sebab timbulnya plagiarisme (Smith dkk, 2007; Koh dkk, 2011; Ahmadi., 2014; Dhusia, 2017; Jereb dkk., 2018). Penelitian-penelitian terdahulu umumnya mengidentifikasi bagaimana kemudahan teknologi seperti internet mempermudah mahasiswa untuk melakukan tindakan plagiarisme (Ahmadi, 2014; Jereb dkk., 2018). Sementara penelitian Smith dkk (2007) fokus pada sifat personal yang dapat menimbulkan kecenderungan seseorang melakukan tindakan plagiarisme. Sementara, Dhusia (2017) membahas mengenai strategi-strategi yang dapat dilakukan dalam mencegah plagiarisme. 


\section{Teori Kepatuhan}

Teori kepatuhan fokus pada pada perilaku yang "direncanakan" bukan prilaku yang "otomatis", memiliki orientasi dengan tujuan yang jelas (Etienne, 2011). Kepatuhan mengacu kepada respon tertentu yang disebabkan karena adanya persetujuan dan permintaan, permintaan dapat saja secara eksplisit dan target atau orang yang diminta untuk patuh mengetahui bahwa mereka didesak untuk bertindak sesuai dengan yang diinginkan (Cialdini dan Goldstein, 2004). Kepatuhan didasarkan pada perilaku yang dilakukan karena adanya tekanan. Kepatuhan selalu memiliki kaitan yang erat dengan hukum. Tyler (1990) menyatakan bahwa jika orang memandang kepatuhan terhadap hukum merupakan hal yang tepat sesuai dengan bagaimana mereka seharusnya berperilaku, maka mereka akan secara sukarela menanggung kewajiban untuk mengikuti aturan hukum. Dalam hal ini secara pribadi, mereka akan berkomitmen untuk mematuhi hukum terlepas dari apakah ada risiko untuk mendapatkan hukuman apabila melanggar hukum atau tidak.

\section{Regulasi}

Regulasi merupakan unsur penting dalam tata kelola sebuah organisasi. Regulasi dapat dikatakan sebagai salah satu cara untuk mengontrol orang-orang yang ada di dalam organisasi. Regulasi kadang-kadang menuntut regulator untuk melakukan perbuatan yang tidak menyenangkan (Etienne, 2011). Etienne (2011) lebih lanjut menjelaskan bahwa secara umum, teori kepatuhan mengimplikasikan subjektif dari berbagai bentuk dan tingkat yang bisa saja tidak menyenangkan. Disamping, pelaksanaannya bisa saja tidak adil, tidak menghargai, atau terkadang menghina. Sedangkan sanksi atau hukuman dapat menyebabkan timbulnya rasa malu, rasa bersalah, dan rasa marah (Sherman, 1993).

Regulasi berhubungan erat dengan tingkat hukuman. Munculnya hukuman dan sanksi seringkali ditandai dengan adanya regulasi tertentu. Regulasi seringkali menekan seseorang untuk melakukan tindakan sesuai dengan apa yang diinginkan (Etienne, 2011). Oleh karena itu, penekanan adanya regulasi bahwa melakukan plagiarisme dilarang dengan keras akan menyebabkan mahasiswa cenderung menghindari tindakan plagiarisme tersebut sehingga tindakan plagiarisme akan berkurang. Begitupun sebaliknya, jika regulasi mengenai plagiarisme tidak diterapkan dan semakin lemah maka kecenderungan seseorang melakukan plagiarisme akan semakin tinggi.

H1a : Semakin lemah regulasi yang diterapkan, akan semakin rendah sanksi terhadap kecurangan.

H1b : Semakin lemah regulasi yang diterapkan, akan semakin tinggi tindakan plagiarisme.

\section{Sanksi}

Ketakutan akan sanksi dapat menimbulkan efek yang positif dalam organisasi (Teraji, 2013). Banyak organisasi yang menerapkan sanksi di dalam organisasi mereka. Baik itu dilakukan dengan cara pemotongan gaji, penundaan pembayaran tunjangan, serta yang paling fatal adalah pemecatan. Sebagai sebuah organisasi yang menghasilkan para akuntan di masa depan, instansi pendidikan harus turut andil di 
dalam membentuk perilaku mahasiswanya agar bertindak secara profesional dan etis. Penerapan hukuman di dalam organisasi dapat menjadi salah satu alat yang mengontrol tingkah laku mahasiswa.

Teori kepatuhan fokus pada prilaku yang direncanakan, yang artinya dengan adanya hukuman, maka mahasiswa akan berusaha untuk tidak akan melakukan plagiarisme karena menghindari hukuman yang ditetapkan. Hal ini kemudian memunculkan gagasan sesuai dengan teori kepatuhan bahwa mahasiswa akan bertindak sesuai dengan yang direncanakan. Sanksi dapat menyebabkan rasa malu, rasa bersalah, dan kemarahan (Sherman, 1993). Oleh karena itu, seseorang akan cenderung menghindari sanksi. Apabila melakukan tindakan plagiarisme akan dikenakan sanksi yang berat, maka seseorang akan cenderung menghindari tindakan plagiarisme. Jika di dalam organisasi tidak diterapkan dan diatur sanksi mengenai tindakan plagiarisme, maka kecenderungan seseorang untuk melakukan plagiarisme akan semakin meningkat. Oleh karena itu:

H2: Semakin lemah sanksi, maka akan semakin tinggi tindakan plagiarisme.

\section{Gambar 1. Rerangka Penelitian}

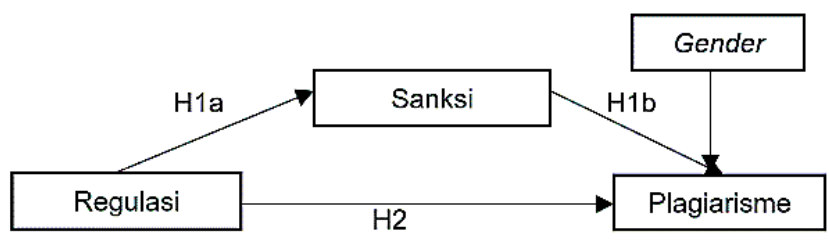

Sumber : Sherman (1993)

\section{METODE PENELITIAN}

\section{Tempat, Waktu, dan Subjek Penelitian}

Penelitian ini dilakukan di Politeknik Negeri Bengkalis, khususnya pada Program Studi Akuntansi Keuangan Publik. Penelitian dilakukan dalam kurun waktu 2 minggu dari tanggal 16 September hingga 30 September 2019. Subjek penelitian adalah mahasiswa/i Program Studi D-IV Akuntansi Keuangan Publik Politeknik Negeri Bengkalis berjumlah 44 orang partisipan.

\section{Teknik Pengumpulan Data}

Penelitian ini menggunakan metode survei dengan 44 partisipan yang berasal dari mahasiswa Akuntansi Politeknik Negeri Bengkalis. Kuesioner yang disebarkan kepada mahasiswa sebelumnya sudah dilakukan uji pilot terkait dengan apakah isi dari kuesioner sudah dipahami oleh responden atau belum. Uji pilot dilakukan untuk menguji sebagian kecil populasi dengan tujuan apakah isi dari kuesioner sudah cukup dipahami atau belum (Hartono, 2011). Setelah dilakukan uji pilot, kemudian kuesioner disebarkan secara online kepada mahasiswa akuntansi Politeknik Negeri Bengkalis. Analisis data di dalam penelitian ini menggunakan Structural Equation Modeling (SEM) dengan WarPLS 3.0. 
Tabel 1. Karakteristik Demografis Sampel

\begin{tabular}{|c|c|c|c|c|c|}
\hline Keterangan & & Jumlah & Persentase & Jumlah & Persentase \\
\hline Jenis Kelamin & Laki-Laki & 10 & $22.73 \%$ & \multirow[b]{3}{*}{44} & \multirow[b]{3}{*}{$100 \%$} \\
\hline & Perem-puan & 34 & $77.27 \%$ & & \\
\hline & & & Total & & \\
\hline \multirow[t]{8}{*}{ Usia } & 17 tahun & 1 & $2.27 \%$ & \multirow[b]{8}{*}{44} & \multirow[b]{8}{*}{$100 \%$} \\
\hline & 18 tahun & 4 & $9.09 \%$ & & \\
\hline & 19 tahun & 8 & $18.18 \%$ & & \\
\hline & 20 tahun & 9 & $20.45 \%$ & & \\
\hline & 21 tahun & 17 & $38.64 \%$ & & \\
\hline & 22 tahun & 2 & $4.55 \%$ & & \\
\hline & 23 tahun & 3 & $6.82 \%$ & & \\
\hline & & & Total & & \\
\hline \multirow[t]{5}{*}{ Se-mester } & I & 3 & $6.82 \%$ & \multirow{5}{*}{44} & \multirow{5}{*}{$100 \%$} \\
\hline & III & 7 & $15.91 \%$ & & \\
\hline & $\mathrm{V}$ & 14 & $31.82 \%$ & & \\
\hline & VII & 20 & $45.45 \%$ & & \\
\hline & & & Total & & \\
\hline
\end{tabular}

Sumber: Data Primer, diolah (2019)

\section{Pengukuran Variabel}

Untuk setiap pengukuran variabel skala likert 1-5 digunakan dengan angka 1: sangat tidak setuju, 2: tidak setuju, 3: netral, 4: setuju, 5: sangat setuju. Untuk mengantisipasi kesulitan responden dalam memahami isi dari kuesioner yang dibagikan, peneliti terlebih dahulu akan melakukan uji pilot. Hasil uji pilot menunjukkan bahwa kuesioner sudah cukup dimengerti kemudian dilakukan beberapa perbaikan. Setelahnya, kuesioner disebarkan kembali kepada mahasiswa Akuntansi Keuangan Publik di Politeknik Negeri Bengkalis.

1. Variabel Independen

Variabel independen di dalam penelitian ini adalah regulasi. Item pertanyaan diperoleh dan dikembangkan oleh Jereb dkk (2018) yang berisi 7 item pertanyaan mengenai persepsi mahasiswa mengenai peraturan yang ada di kampus.

2. Variabel Pemediasi

Variabel pemediasi di dalam penelitian ini adalah sanksi. Sanksi di ukur dengan menggunakan item kuesioner yang diadopsi dari Jereb dkk (2018) yang berisi lima item kuesioner. Item kuesioner menanyakan persepsi mahasiswa mengenai sanksi yang ada jika mereka melakukan plagiat. Item ini merupakan bagian dari item regulasi yang kemudian diadopsi dan dirubah sesuai dengan tujuan penelitian oleh peneliti demi keperluan penelitian ini.

3. Variabel Dependen

Variabel dependen di dalam penelitian ini adalah plagiarisme. Kuesioner di adopsi dari item pertanyaan yang dikembangkan oleh Ahmadi (2014) yang berisikan sembilan bulir pertanyaan mengenai karakteristik dari plagiarisme. 


\section{Variabel Kontrol}

Variabel kontrol yang dipakai di dalam penelitian ini adalah gender. Hasil survei menunjukkan bahwa dibandingkan laki-laki, wanita cenderung berpikir sanksi karena ketidakpatuhan atau kecurangan yang akan mereka terima akan sangat berat, sehingga mereka cenderung menghindarinya (Kinsey, 1992). Oleh karena itu, penting untuk mengontrol pengaruh gender terhadap plagiarisme. Penelitian ini juga mengontrol jenis kelamin, usia dan semester. Dari hasil analisis (tidak dilaporkan) mengindikasikan bahwa ketiga variabel kontrol ini tidak berkorelasi dengan variabel dependen, sehingga peneliti memutuskan untuk menghapus dari analisis selanjutnya (Becker, 2005).

\section{Metode Statistik}

Analisis data dalam penelitian ini menggunakan analisis statistic SEM-PLS (Structural Equation Modeling-Partial Least Square) dengan program WarPLS 3.0. Analisis multivariate merupakan aplikasi metode statistika untuk menganalisis beberapa variabel penelitian secara simultan atau serempak (Sholihin dan Ratmono, 2013).

\section{Analisis Pengukuran Variabel}

Pengukuran variabel dilakukan dengan menguji validitas konvergen dan validitas diskriminan. Untuk pengujian validitas konvergen, rule of thumb yang dapat digunakan adalah factor loading $>0,7$, communality $>0,5$ dan average variance extracted (AVE) > 0,5 (Chin, 1995 dalam Hartono, 2011). Beberapa indikator yang memiliki loading dibawah 0,4 di drop (Hair dkk., 2013). Sedangkan beberapa dengan loading antara 0,4 - 0,7 dipertahankan untuk validitas isi konstruk (Hair dkk., 2013). Nilai AVE dari masing-masing variabel menunjukkan nilai di atas 0.5 , kecuali $\mathrm{P}$ yang menunjukkan nilai 0.491 namun masih mendekati angka 0.5 .

Hal ini menunjukkan bahwa validitas konvergen telah terpenuhi. Validitas diskriminan terpenuhi jika akar AVE lebih tinggi dari korelasi antar variabel latin. Pada tabel 1 menjelaskan bahwa validitas diskriminan telah terpenuhi dengan akarAVE (yang ditunjukkan pada kolom diagonal dan diberi tanda kurang) nilainya lebih tinggi daripada korelasi antar variabel laten pada kolom selain kolom diagonal.

Tabel 2. Correlation among Latent Variables.

\begin{tabular}{|c|c|c|c|c|}
\hline \multicolumn{5}{|c|}{ Latent variable correlations } \\
\hline & $\mathrm{R}$ & $\mathrm{S}$ & $\mathrm{P}$ & Gender \\
\hline $\mathrm{R}$ & 0.807 & 0.616 & 0.424 & 0.009 \\
\hline$S$ & 0.616 & 0.782 & 0.62 & 0.08 \\
\hline $\mathrm{P}$ & 0.424 & 0.62 & 0.701 & -0.188 \\
\hline Gender & 0.009 & 0.08 & -0.188 & 1 \\
\hline
\end{tabular}

Sumber: Hasil Penelitian, diolah (2019)

Keterangan: R (Regulasi), S (Sanksi), P (Plagiarisme). 
Tabel 3. Laten Variable Coefficients

\begin{tabular}{|l|l|l|l|l|}
\hline & $\mathrm{R}$ & $\mathrm{S}$ & $\mathrm{P}$ & Gender \\
\hline R-Squared & & 0.395 & 0.461 & \\
\hline Composite reliability & 0.928 & 0.887 & 0.869 & 1 \\
\hline Cronbach's alpha & 0.909 & 0.84 & 0.824 & 1 \\
\hline Avg. var. extrac. & 0.652 & 0.612 & 0.491 & 1 \\
\hline Full collin VIF & 1.619 & 2.282 & 1.793 & 1.11 \\
\hline Q-squared & & 0.401 & 0.473 & \\
\hline
\end{tabular}

Sumber: Hasil Penelitian, diolah (2019)

Tabel 3 menunjukkan bahwa nilai Cronbach's alpha setiap indikator variabel laten lebih besar dari $0,7(>0.7)$ sehingga memenuhi asumsi reliabilitas. Tabel 3 juga menunjukkan nilai composite reliability telah memenuhi reliabilitas kontruk model terdukung dengan nilai composite reliability setiap variabel laten lebih besar dari 0,7 $(>0,7)$.

\section{Analisis Model Struktural}

Gambar 2. Model Struktural

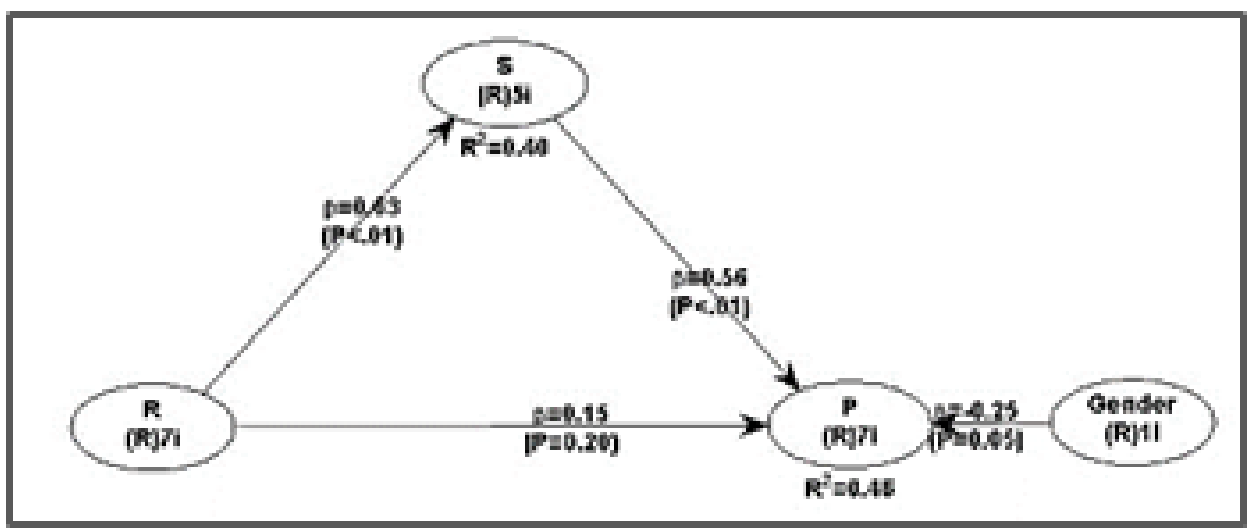

Sumber : Hasil Penelitian, diolah (2019)

Dari Gambar 2 dapat dilihat nilai $\mathrm{R}^{2}$ untuk variabel $\mathrm{S}$ sebesar 0,40 yang berarti bahwa $40 \%$ variabel Sanksi dijelaskan oleh variabel Regulasi serta sisanya dijelaskan oleh variabel lain diluar model. Selanjutnya nilai $\mathrm{R}^{2}$ untuk variabel plagiarisme adalah sebesar 0,46 yang berarti $46 \%$ variabel plagiarisme dijelaskan oleh variabel regulasi dan sanksi, sementara sisanya dijelaskan oleh variabel lain diluar model yang diajukan. Tabel 3 juga menyajikan nilai full collinearity VIF. Rule of thumb untuk full collinearity test adalah lebih rendah dari 3,3. Output yang disajikan pada tabel 3 menunjukkan nilai full collinearity test lebih rendah dari 3,3. Hal ini menunjukkan model bebas dari masalah kolinearitas vertical, lateral, dan common method bias.

Tabel 4. Indikator model fit dan $P$ values

\begin{tabular}{|l|}
\hline $\mathrm{APC}=0.396, \mathrm{P}<0.001$ \\
\hline $\mathrm{ARS}=0.428, \mathrm{P}<0.001$ \\
\hline $\mathrm{AVIF}=1.361$, Good if $<5$ \\
\hline
\end{tabular}

Sumber: Hasil Penelitian, diolah (2019)

Model penelitian dapat dikatakan sebagai model yang fit atau sesuai (didukung oleh data) ketika nilai P dari APC dan ARS yang ditunjukkan lebih kecil dari 0,05 atau 
signifikan dan nilai AVIF (variance inflation factor) yang ditunjukkan lebih kecil dari 5 (Sholihin dan Ratmono, 2011). Sesuai dengan yang ditunjukkan oleh Tabel 4, nilai dari APC dan ARS terlihat signifikan pada <0,001 dan nilai AVIF di bawah 5, yang menunjukkan bahwa model penelitian ini telah sesuai dan didukung oleh data.

\section{HASIL PENELITIAN DAN PEMBAHASAN \\ Hasil Penelitian \\ Pengujian Hipotesis}

Uji hipotesis dilakukan dengan melihat signifikansi yang ada yaitu nilai p. Jika nilai $\mathrm{p}<0,01$ maka signifikan di level $1 \%$, dan jika $\mathrm{p}<0,05$ maka signifikan di level $5 \%$. Hipotesis 1a memprediksi pengaruh positif dari ketiadaan regulasi terhadap sanksi. Hipotesis $1 \mathrm{~b}$ memprediksi pengaruh positif dari diabaikannya sanksi terhadap tindakan plagiarisme. Sedangkan set hipotesis 2 memprediksi pengaruh positif regulasi terhadap plagiarisme. Tiga hipotesis ini diuji secara simultan. Hasil ditunjukkan pada Tabel 5.

Tabel 5.Path Coefficient, P Values dan R-Squared
\begin{tabular}{|l|l|l|l|}
\hline Path & Path Coefficient & P Values & R-Squared \\
\hline R-S & 0.629 & $<0.001$ & 0.395 \\
\hline S-P & 0.556 & $<0.001$ & 0.461 \\
\hline R-P & 0.150 & 0.202 & 0.461 \\
\hline R-S-P & 0.349 & $<0.001$ & 0.461 \\
\hline
\end{tabular}

Sumber: Hasil Penelitian, diolah (2019)

Keterangan: P (plagiarisme), R (regulasi), S (sanksi).

Tabel 5 menunjukkan bahwa pengaruh dari regulasi terhadap sanksi terdukung dengan koefisien $0,629(\mathrm{p}<0,001)$ dan $\mathrm{R}^{2}$ bernilai 0,395 . Hal ini menunjukkan bahwa Hipotesis 1a terdukung. Pengaruh dari sanksi terhadap tindakan plagiarisme terdukung dengan koefisien 0,556 ( $\mathrm{p}<0,001)$, hipotesis $1 \mathrm{~b}$ terdukung. Untuk hipotesis 2 , nilai koefisien menunjukkan bahwa pengaruh regulasi terhadap tindakan plagiarisme tidak terdukung dengan koefisien $0,150 \quad(\mathrm{p}=0,202)$, hipotesis 2 tidak terdukung. Untuk hubungan mediasi antara regulasi terhadap tindakan plagiarisme melalui sanksi menunjukkan nilai koefisien $0,349(\mathrm{p}<0,01)$ hal ini menunjukkan memang terdapat mediasi yang signifikan yang diwakili oleh sanksi dalam hubungan antara regulasi terhadap tindakan plagiarisme.

\section{Pembahasan}

Hasil penelitian menunjukkan bahwa tidak adanya regulasi maka akan meningkatkan kecenderungan mahasiswa melakukan tindakan plagiarisme dimediasi oleh tidak adanya sanksi. Hal ini sesuai dengan Etienne (2011) yang menyatakan bahwa keberadaan regulasi dapat menekan seseorang untuk melakukan tindakan yang diinginkan. Sehingga, jika tidak ada regulasi yang mengatur mengenai tindakan plagiarisme ini maka kecenderungan mahasiswa untuk melakukannya semakin tinggi. Selain itu, regulasi erat kaitannya dengan sanksi. Keberadaan sanksi sangat penting untuk diterapkan di perguruan tinggi. Hal ini disebabkan karena ketakutan akan sanksi dapat menimbulkan efek yang positif dalam organisasi termasuk perguruan tinggi (Teraji, 2013). Mahasiswa akan cenderung menghindari sanksi karena sanksi dapat menyebabkan rasa malu, rasa bersalah, dan kemarahan (Sherman, 1993). Oleh karena 
itu, sesuai dengan hasil penelitian. Tidak adanya regulasi dan sanksi akan cenderung meningkatkan perilaku mahasiswa dalam melakukan tindakan plagiarisme.

\section{KESIMPULAN}

Penelitian ini memperkaya hasil penelitian di ranah melayu, yang menunjukkan bahwa penting sekali mempertimbangkan adanya regulasi dan sanksi untuk menghindari terjadinya kecurangan yang tidak diinginkan di ranah akademik seperti plagiarisme. Hasil penelitian dengan arah mediasi menunjukkan hasil yang signifikan bahwa ketiadaan regulasi yang dimediasi dengan rendahnya sanksi akan menyebabkan tingginya tingkat plagiarisme. Hasil penelitian juga menunjukkan bahwa tidak ada pengaruh yang signifikan dari regulasi terhadap plagiarisme tanpa adanya mediasi variabel sanksi, yang menunjukkan bahwa tanpa variabel sanksi kecenderungan mahasiswa untuk melakukan tindakan plagiarisme tetap akan meningkat, meskipun sudah ditetapkan regulasi di instansi. Penelitian ini memiliki beberapa keterbatasan, penelitian ini merupakan penelitian survei yang tentunya tidak terlepas dari masalah validitas dan reliabilitas data. Selain itu, pemilihan objek penelitian yang hanya fokus pada satu instansi menyebabkan hasil penelitian tidak bisa digeneralisasi. Namun, keterbatasan ini tentunya disesuaikan dengan ruang lingkup penelitian dengan tujuan yang berfokus pada perilaku mahasiswa Akuntansi Politeknik Negeri Bengkalis. Penelitian ini berguna bagi arah penelitian selanjutnya sebagai dasar penelitian mengenai plagiarisme di Kabupaten Bengkalis. Namun, beberapa instansi sudah mulai menerapkan sistem deteksi plagiarisme yang biasanya dikenal dengan uji turnitin yang dapat menjadi fokus bagi penelitian selanjutnya sebagai salah satu anteseden yang dapat mengurangi tindakan plagiarisme.

\section{DAFTAR PUSTAKA}

-----. 2008. Oxford Learner's Pocket Dictionary. New York: Oxford University Press.

Ahmadi, Alireza. 2014. Plagiarism in The Academic Context: A Study of Iranian EFL Learners. Research Etics, Vol. 10 (3), pp 151-168.

Becker, Thomas E. 2005. Potential Problems in the Statistical Control of Variables in Organizational Research: A Qualitative Analysis with Recommendations. Organizational Research Methods, Vol.8, pp. 274-289.

Cialdini, Robert B., dan Noah J. Goldstein. 2004. Social Influence: Compliance and Conformity. Annual Review of Psychology, Vol 55, pp, 591-621.

Devlin, M., dan K. Gray. 2007. In Their Own Words: A Qualitative Study of The Reasons Australian University Students Plagiarize. Higher Education Research and Development, Vol 26, pp 181-198.

Dhusia, Devendra Kumar. 2017. Strategies for Prevening Plagiarism - A Case Study of Top Indian Universities. Global Journal of Enterprise Information System, Vol. 9, Issue 2.

Etienne, Julien. 2011. Compliance Theory: A Goal Framing Approach. Law \& Policy, Vol, 33, No. 3, pp. 305-333.

Guo, Xin. 2011. Understanding Student Plagiarism: An Empirical Study in Accounting Education. Accounting Eduaction: an International Journal, Vol 20, No. 1, pp. 17-37. 
Hair, Joe., Hult, Thomas M., Ringle, Christian M., dan Marko Sartstedt. 2013. A Primer on Partial Least Squares Structural Equation Modeling (PLS-SEM). Los Angeles; Sage.

Hartono, Jogiyanto. 2011. Konsep dan Aplikasi Structural Equation Modeling Berbasis Varian Dalam Penelitian Bisnis. Yogyakarta: UPP STIM YKPN.

ICAS. 2007a. Clearly Ahead. Edinburgh: ICAS.

ICAS. 2007b. IVE-Living Up to Our Values. Edinburgh: ICAS.

IFAC. 2007. Approaches to Developing and Maintaning Professional Value, Ethics, and Attitudes. IFAC: New York.

James, R., C. McInnis, dan Devlin M. 2002. Assessing Learnings in Australian Universities: Ideas, Strategies and Resources for Quality in Assessment. University of Melbourne for the Australian Universities Teaching Committee, Department of Education, Science and Training (DEST), Centre for the Study of Higher Education: Australia.

Jereb, Eva., Perc, Matjaz., Lammlein, Barbara., Jerebic, Janja., Urh, Marko., Podbregar, Iztok., dan Polona Sprajc. 2018. Factors Infuencing Plagiarism in Higher Education: A Comparison of German and Slovene Students. PLoS One, Vol 13 (8), pp 1-16.

Kinsey, K. A. 1992. Deterrence and Alienation Effects of IRS Enforcement: An Analysis of Survey Data, in Joel Slemrod (ed), Why People Pay Taxes: Tax Compliance and Enforcement (The University of Michigan Press, Ann Arbor), pp. 259-285.

Koh, Hwee Ping., Scully, Glennda., dan David R. Woodliff. 2011. The Impact of Cumulative Pressure on Accounting Students' Propensity to Commit Plagiarism: an Experimental Approach. Accounting and Finance, Vol. 51, pp. 985-1005.

Maurer, Hermann., Kappe, Frank., dan Bilal Zaka. 2006. Plagiarism - A Survey. Journal of Universal Computer Science, Vol. 12, No. 8, pp. 1050-1084.

Sherman, Lawrence W. 1993. Defiance, Deterrence, and Irrelevance: A Theory of the Criminal Sanction. Journal of Research in Crime and Delequency, Vol 30, pp 445-73.

Sholihin, Mahfud dan Ratmono, Dwi. 2013. Analisis SEM-PLS dengan WrapPLS 3.0 Untuk Hubungan Nonlinear dalam Penelitian Sosial dan Bisnis. Yogyakarta: Penerbit ANDI.

Smith, Sir Robert. 2003. Audit Committees Combined Code Guidance: A report and proposed guidance by an FRC-appointed group. The Financial Reporting Council Limited.

Smith, Malcolm., Ghazali, Noorlaila, dan Siti Fatimah Noor Minhad. 2007. Attitudes Towards Plagiarism Among Undergraduate Accounting Students: Malaysian Evidence. Asian Review of Accounting, Vol. 15, Issue 2, pp. 122-146.

Teraji, Shinji. 2013. A Theory of Norm Compliance: Punishment and Reputation. The Journal of Socio-Economics, Vol. 44, pp. 1-6.

The Corporate Law Economic Reform Program (Audit Reform \& Corporate Disclosure) Act. 2004. Australia. 
Tyler, Tom R. 1990. Why People Obey the Law. Yale University Press: New Haven and London.

United States. 2002. Sarbanes-Oxley Act of 2002: conference report (to accompany H.R. 3763). [Washington, D.C.]: [U.S. G.P.O.].

https://www.checkforplagiarism.net/cyber-plagiarism diakses 26 november 2019 pukul 10.45 wib. 